\title{
An Experience of Using the Harmony Test for Genomics-Based Non-Invasive Prenatal Testing
}

Dong Hee Seo, Sung Eun Cho, and Jeong Ryull Kwak

LabGenomics Clinical Laboratories, Seongnam, Korea

Corresponding author: Dong Hee Seo LabGenomics Clinical Laboratories, 700 Daewangpangyo-ro, Bundang-gu, Seongnam 463-400, Korea Tel: +82-31-628-0730 Fax: +82-31-628-0701 E-mail: seo2023@nate.com

pISSN: 1225-097X elSSN: 2288-7261

\begin{abstract}
Serological prenatal screening tests are widely used to detect fetal chromosomal abnormalities such as Down and Edward syndromes. Amniocentesis is conducted as a confirmatory test in the screening-positive case. After discovering of presence of fetal cellfree DNA in maternal blood, non-invasive prenatal test (NIPT) coupled with next generation sequencing are performed in abroad. Results of genomics-based NIPT results supplied to Labgenomics laborotory from June, 2013 to August, 2014 were analyzed. Maternal blood samples were collected into specific Cell-Free DNA BCT tube and were transported. The samples were then delivered to Ariosa Diagnostics by FEDEX. Fetal cell-free DNA samples were analyzed using the Harmony test with sequencing of relevant chromosomes and by using the FORTE (fetal-fraction optimized risk of trisomy evaluation) algorism at Ariosa Diagnostics. In all, 149 cases from 28 medical clinics were analyzed. Six subjects were required recollection of samples because of a low fetal DNA fraction in the initially obtained samples. Of these 6 subjects, no sample could be collected from one. Of the remaining 148 cases, 144 had a low risk of trisomy, and 4 had a high risk for Down syndrome, thus providing a positivity percentage of $2.7 \%$. Fetal DNA fraction in the maternal blood samples ranged from $4.2 \%$ to $23.7 \%$ with a mean value of $12.0 \%$. We have experienced cases with a high risk for Down syndrome with genomics-based NIPT referred to abroad.
\end{abstract}

(J Lab Med Qual Assur 2015;37:44-46)

Key Words: Non-invasive prenatal test, Harmony test, Cell-free DNA, Fetal DNA fraction

Received November 20, 2014, Revision received December 30, 2014, Accepted January 14, 2015
다운증후군, 에드워드증후군 등 태아의 염색체 이상 유무를 알기 위해 목덜미투명대(nucal translucency) 초음파검사와 혈청 생화학적 표지자를 이용한 산전 선별검사가 국내에서 널 리 이용되고 있다[1-3]. 이들 산전 선별검사에서 양성을 보이 는 경우 양수천자 또는 융모막천자를 통해 염색체검사로 태아 의 염색체 이상 여부를 확인하고 있다. 하지만 혈청선별검사 는 위양성률이 높다는 단점이 있고, 양수천자는 침습적 시술로 인한 산모의 높은 심리적 부담, 태아 소실 등의 문제점이 있다. 이에 최근에 산모의 혈액에 존재하는 태아의 유리 핵산(cell free DNA)으로 산전진단을 하는 소위 유전체 기반(genomicsbased) 비침습적 산전검사(noninvasive prenatal testing, $\mathrm{NIPT}$ )가 소개되었다[4]. 현재 Sequenom, Verinata Health, Ariosa Diagnostics, Natera 등의 유전체 분석회사들에 의해 상업화된 서비스가 제공되고 있다[5]. 유전체 기반 NIPT는 대 규모 병렬염기분석(massively parallel sequencing)법으로 산
모 및 태아 유래의 DNA 분절을 증폭하여 전산화된 생물정보 학(bioinformatics)을 이용하여 해당 염색체의 상대적인 발현 양을 통계적으로 분석한다[6]. 유전체 기반 NIPT가 새로운 의 료기술로 아직 신의료기술행위로 인정을 받지 않은 상태여서 국내에서는 아직 시행하지 못하고 있으며, 국외 유전체 분석회 사에 의뢰하고 있다. 랩지노믹스 검사센터에서도 2013년 6월 부터 미국의 Ariosa Diagnostics에 유전체 기반 NIPT를 의뢰 하고 있다.

랩지노믹스 검사센터에서 유전체 기반 NIPT를 시작한 2013 년 6월부터 2013년 12월까지 47건, 2014년 1월부터 2014년 8 월말까지 102 건으로 총 149 건의 검사가 28 개 의료기관으로 부터 의뢰되었다. 유전자검사에 동의한 산모의 혈액은 전용용 기인 Streck (Streck Laboratories, Omaha, NE, USA)사의 Cell-Free DNA BCT 튜브에 채혈되어 랩지노믹스 검사센터 에 운송된 후, 페덱스를 통해 미국 Ariosa Diagnostics (San 
Journal of LABORATORY MEDICINE and QUALITY ASSURANCE

Dong Hee Seo et al • Experience of Genomics-Based Non-Invasive Prenatal Testing

Table 1. Characteristics of cases tested positive by genomics-based non-invasive prenatal testing

\begin{tabular}{ccccccc}
\hline Case no. & Age (yr) & Gestational age (wk) & Fetal fraction (\%) & In vitro fertilization & No. of fetus & Result \\
\hline 1 & 34 & 11 & 18.9 & No & 1 & Trisomy 21, high risk \\
2 & 35 & 11 & 10.4 & No & Twin & Trisomy 21, high risk \\
3 & 38 & 12 & 11.4 & No & 1 & Trisomy 21, high risk \\
4 & 43 & 18 & 12.0 & No & 1 & Trisomy 21, high risk \\
\hline
\end{tabular}

Jose, CA, USA) 검사실로 보내어졌다. Ariosa Diagnostics 검사실에서는 Harmony 검사명으로 표적 유전체 염기서열 분석법과 FORTE (fetal-fraction optimized risk of trisomy evaluation) 생물정보학 알고리즘을 이용하여 태아의 유리 핵 산이 분석되었다. 총 149 건의 의뢰건 중에서 6 건은 산모 혈액 내 태아 분획(fetal fraction)이 낮아서 재검을 위해 재채혈이 요구되었다. 재검이 시행된 5건은 삼배수체(trisomy) 저위험 군으로 결과가 나왔고, 한 건은 재재혈이 되지 않아 재검이 진 행되지 못했다.

태아 유전체 검사결과가 나온 148 건의 검사 중 144 건은 삼 배수체 저위험군으로, 4 건은 다운증후군 고위험군으로 양성을 보여 검사 양성률은 $2.7 \%$ 였다. 검사가 의뢰된 산모의 나이는 25 세부터 45 세까지 분포하였고, 중위값은 36 세였다. 혈액채혈 시 산모의 임신주수는 10 주부터 32 주까지 분포하였다. 산모 혈액에서 측정한 태아 DNA 분획은 $4.2 \%$ 에서 $23.7 \%$ 까지의 범위를 보였고, 평균값은 $12.0 \%$ 였다. 검사 의뢰건 148 건 중 47건은 체외수정으로 인한 임신이었고, 쌍태아 의뢰건은 148 건 중 13 건이었다. 다운증후군 고위험 양성을 보인 4 건의 산 모의 나이는 모두 34세 이상이었으며, 임신 주수 등의 특성을 Table 1에 나타내었다. Table 1에서 증례 4번은 임신 초기 이 중표지자검사에서도 다운증후군과 에드워드증후군 고위험군 결과를 보였다.

산모 혈액 속의 태아 유리 DNA는 약 $150 \mathrm{bp}$ 길이의 짧은 핵산 분절로 태반에서 유래한다. 태아 유리 DNA는 산모 혈액 내의 전체 유리 DNA의 약 $10 \%$ 를 차지하며, 임신 4 주째부터 산모의 혈액에 나타나기 시작하여, 임신 10 주에는 약 $4 \%$ 를 차 지한다[7]. 태아 유리 DNA는 분만 후 2시간 이후에는 검출되 지 않는다[8]. 유전체 기반 NIPT가 검사 민감도가 높고, 위양 성률이 낮지만, 미국산부인과학회에서는 35 세 이상 산모, 혈 청학적 선별검사 양성, 삼배수체 이상의 과거력 등 고위험군 산모에서 산전 선별검사로 사용할 것을 권장하고 있다[9]. 미 국에서는 양수천자의 비용이 유전체 기반 NIPT 산전검사 비 용보다 높아서 고위험군 산모에서 유전체 기반 NIPT 산전검 사법 적용이 확산되고 있지만, 국내에서는 그 반대의 상황이라 서 아직 활성화되고 있지 않다. 유전체 기반 NIPT 산전검사가
신의료기술로 인정받아 국내에서 시행되면 검사 건수가 증가 할 것으로 기대된다.

랩지노믹스 검사센터에 의뢰된 148 건의 Harmony 검사 중 4건이 다운 고위험군 양성을 보여 $2.7 \%$ 의 검사 양성률을 보였 다. Han 등[10]에 의하면 국내 임신 중기 양수천자의 염색체 이상이 $3.1 \%$ 로 보고되어 있는데, 단순 비교의 한계는 있지만 Harmony 검사 양성률도 이와 비슷한 수준을 보이고 있는 것 으로 판단되며, 이는 유전체 기반 NIPT 산전검사가 양수천자 와 비슷한 검사 특이성을 보이는 것으로 여겨진다. 랩지노믹스 검사센터의 특성상 Harmony 검사 양성 증례의 양수천자 결 과를 확인할 수 없어 검사의 정확도를 확인할 수 없었던 한계 가 있다. 랩지노믹스 검사센터에서 미국에 의뢰한 Harmony 검사 149 건 중 한 건에 대해서는 결과를 얻지 못했다. 이는 검 체 혈액 내 fetal DNA fraction이 낮아서 검사에 실패한 것으 로 추정되며, 유전체 기반 NIPT 산전검사의 검사 실패율은 $1-5 \%$ 로 보고되어 있다[8]. Harmony 검사에서 fetal DNA fraction은 중요한 요소이고, 검체 혈액 내 fetal DNA fraction 이 $4.0 \%$ 이상이어야 정상적인 검사 진행이 가능하다.

유전체 기반 NIPT 산전검사는 태아의 개방성 신경관 결손 증의 위험도를 알지 못하기 때문에 현재 널리 사용되고 있는 사중검사 등 혈청학적 산전선별검사도 지속적으로 필요하다 고 본다. 다만 태아의 삼배수체 이상이 예상되는 상황에서, 산 모가 양수천자를 두려워하는 경우 등에서 양수천자를 시행하 기 전에 비침습적으로 한 번 더 선별할 수 있는 검사로 유전 체 기반 NIPT를 이용할 수 있을 것이다. 이렇게 유전체 기반 $\mathrm{NIPT}$ 산전검사로 추가적으로 염색체 이수성을 선별을 하게 되면 위양성률이 높은 혈청학적 선별검사 양성으로 인해 양수 천자를 시행하는 경우를 줄일 수 있을 것으로 기대된다.

\section{REFERENCES}

1. Hwang D. The recent trend of prenatal screening. J Genet Med 2008;5:7-14.

2. Kim S, Kim YH, Min WK. Prenatal serum marker screening in Korea: survey results. Korean J Lab Med 2007; 
27:28-33.

3. Yi DY, Jung B, Kang MS, Huh JY, Paek JY, Cha DH, et al. The evaluation of integrated test as an antenatal screening test for Down's syndrome in Korea. Lab Med Online 2011;1:10-8.

4. Morain S, Greene MF, Mello MM. A new era in noninvasive prenatal testing. N Engl J Med 2013;369:499-501.

5. Yang JI. Clinical application of non-invasive prenatal testing using cell free fetal DNA. J Korean Med Assoc 2014;57:771-9.

6. Lim JH, Park SY, Ryu HM. Non-invasive prenatal diagnosis of fetal trisomy 21 using cell-free fetal DNA in maternal blood. Obstet Gynecol Sci 2013;56:58-66.

7. Gekas J, Langlois S, Ravitsky V, Audibert F, van den Berg
DG, Haidar $\mathrm{H}$, et al. Identification of trisomy 18, trisomy 13, and Down syndrome from maternal plasma. Appl Clin Genet 2014;7:127-31.

8. Lo YM, Zhang J, Leung TN, Lau TK, Chang AM, Hjelm NM. Rapid clearance of fetal DNA from maternal plasma. Am J Hum Genet 1999;64:218-24.

9. American College of Obstetricians and Gynecologists Committee on Genetics. Committee opinion no. 545: noninvasive prenatal testing for fetal aneuploidy. Obstet Gynecol 2012;120:1532-4.

10. Han SH, An JW, Jeong GY, Yoon HR, Lee A, Yang YH, et al. Clinical and cytogenetic findings on 31,615 mid-trimester amniocenteses. Korean J Lab Med 2008;28:378-85.

유전체 기반 비침습적 산전검사인 Harmony 검사 경험 서동희 - 조성은 - 곽정율

랩지노믹스 임상검사센터

다운증후군, 에드워드증후군 등 태아의 염색체 이상을 산전에 알기 위해 혈청학적 산전 선별검사가 널리 사용되고 있다. 이 선별검사에서 양성을 보이는 경우 확인검사로 양수천자를 시행하고 있다. 산 모 혈액 내 태아의 유리 유전체의 존재가 밝혀진 후 차세대 염기서열분석법을 이용한 비침습적 산전 검사(non-invasive prenatal test, NIPT)가 국외에서 시행되고 있다. 2013년 6월부터 2014년 8 월까지 랩지노믹스 검사센터에 의뢰된 유전체 기반 NIPT 결과를 분석하였다. 산모의 혈액은 전용용 기인 Cell-Free DNA BCT 튜브에 채혈되어 랩지노믹스 검사센터에 운송된 후, 페덱스를 통해 미국 Ariosa Diagnostics 검사실로 보내어졌다. Ariosa Diagnostics 검사실에서는 Harmony 검사명으 로 표적 유전체 염기서열분석법과 FORTE (fetal-fraction optimized risk of trisomy evaluation) 알고리즘을 이용하여 태아의 유리 핵산이 분석되었다. 28 개 의료기관으로부터 의뢰된 총 149 건의 검사가 분석되었다. 총 149 건의 의뢰건 중에서 6 건은 산모 혈액 내 태아 분획이 낮아서 재채혈이 요 구되었다. 이 6 건 중 한 건은 재재혈이 되지 않았다. 태아 유전체 검사결과가 나온 148 건의 검사 중 144 건은 삼배수체 저위험군으로, 4 건은 다운증후군 고위험군으로 양성을 보여 검사 양성률은 $2.7 \%$ 였다. 산모 혈액에서 측정한 태아 DNA 분획은 $4.2 \%$ 에서 $23.7 \%$ 까지의 범위를 보였고, 평균값은 $12.0 \%$ 였다. 해외에 의뢰한 유전체 기반 NIPT에서 다운증후군 고위험군 양성을 경험하였다.

(J Lab Med Qual Assur 2015;37:44-46) 